\title{
Implikasi Pendidikan Menurut QS Ali Imran Ayat 35-37 tentang Cara Nabi Zakariya dalam Mendidik Anak Perempuan
}

\author{
Dienan Shafyah Zahrah*, Fitroh Hayati \\ Prodi Pendidikan Agama Islam, Fakultas Tarbiyah dan Keguruan, Universitas \\ Islam Bandung, Indonesia. \\ *dienanzahrah@gmail.com, fitroh.hayati@unisba.ac.id
}

\begin{abstract}
Being a parent is closely related to caring for, nurturing and educating children. Children are a mandate from God to parents for them to always take care, nurture and educate. Parents must be fair to all children, whether they are male or female. They are not treat them differently. The purpose of this research is to find out the educational implications of QS Ali Imran verses 35-37 on how The Prophet Zakariya taught Maryam on girls educating with the following details: (1) finding out the opinions of the mufasirs on the Prophet Zakariya's practices in educating girls from QS Ali Imran verses 35-37, (2) the essence contained in QS Ali Imran verses 35-37, (3) the opinion of education experts on education for girls , and (4) the educational implications of QS Ali Imran verses 35-37 on the Prophet Zakariya's practices on educating girls. The research method used in this study is a descriptive method with the qualitative approach. Whereas for data collecting is technique is literature study. The author used the method of tahlili interpretation approach,namely: describing the meaning contained by the Qur'an, verse by verse in accordance with the order in the mushaf. The content of QS Ali Imran verses 35-37 according to mufassirin is: parents must educate their children in terms of obedience to Allah SWT and provide education to children in order to be a righteous and shalehah child, because the most noble man in the eyes of Allah SWT is a person who fears Him (male or female), not based on gender. The results of the study of QS Ali Imran verses 35-37 are: (1) parents should educate their children in terms of obedience to Allah Almighty, (2) education is given not based on gender, (3) parents must provide the best education for their children, and (4) an educator must provide good education and care. The educational implications contained from QS Ali Imran verses 35-37, namely: (1) parents must educate children to obey Allah Almighty, (2) parents must give the equality of rights of education for children, (3) parents mus be just to all children (male or female) in terms of education, and (4) educators must consider ways to provide education to female learners.
\end{abstract}

Keywords: Parenting, Management, Educating girls.

\begin{abstract}
Abstrak. Menjadi orang tua erat kaitannya dengan mengurus, mengasuh dan mendidik anak. Anak merupakan titipan dari Allah Swt bagi orang tua untuk senantiasa mengurus, mengasuh juga mendidik anak-anaknya. Orang tua haruslah bersikap adil kepada semua anak, entah itu laki-laki ataupun perempuan. Jangan sampai ada perbedaan perlakuan dari orang tua terhadap anak-anaknya. Tujuan penelitian ini adalah untuk mengetahui implikasi pendidikan dari QS Ali Imran ayat 35-37 tentang cara Nabi Zakariya dalam mendidik anak perempuan dengan perincian berikut: (1) mengetahui pendapat para mufasir tentang cara Nabi Zakariya dalam mendidik anak perempuan dari QS Ali Imran ayat 35-37, (2) esensi yang terkandung dalam QS Ali Imran ayat 35-37, (3) pendapat para ahli pendidikan mengenai pendidikan bagi anak perempuan, dan (4) implikasi pendidikan dari QS Ali Imran ayat 35-37 tentang cara Nabi Zakariya dalam mendidik anak perempuan. Metode penelitian yang digunakan ole penulis pada penelitian ini adalah metode deskriptif dengan pendekatan kualitatif dan teknik studi literatur. Penulis menggunakan metode pendekatan tafsir tahlili yaitu: menguraikan makna yang dikandung oleh al-Qur'an, ayat demi ayat sesuai dengan urutannya di dalam mushaf. Isi kandungan QS Ali Imran ayat 35-37 menurut mufassirin adalah: orang tua harus mendidik anaknya dalam hal kepatuhan kepada Allah SWT, memberikan pendidikan kepada anak supaya menjadi anak yang shaleh dan shalehah. Sebab, manusia yang paling mulia di mata Allah SWT merupakan orang yang bertakwa kepada-Nya (laki-laki maupun perempuan) bukan berdasarkan dari jenis kelaminnya. Hasil penelitian dari QS Ali Imran ayat 35-37 adalah: (1) orang tua harus mendidik anaknya dalam hal kepatuhan kepada Allah Swt, (2) pendidikan diberikan bukan berdasarkan jenis kelamin, (3) orang tua harus memberikan pendidikan yang terbaik untuk anaknya, dan (4) seorang pendidik harus memberikan pendidikan dan pengasuhan yang baik. Adapun implikasi pendidikan yang terdapat dari QS Ali Imran ayat 35-37, yaitu: (1) orang tua harus mendidik anak supaya taat kepada Allah Swt, (2) hak pendidikan bagi anak, (3) berbuat adil kepada semua anak (lakilaki ataupun perempuan) dalam hal pendidikan, dan (4) cara-cara pendidik memberikan pendidikan kepada peserta didik perempuan.
\end{abstract}

Kata Kunci: Pengasuhan, Pengurusan, Mendidik anak perempuan. 


\section{A. Pendahuluan}

Pendidikan adalah hak untuk seluruh masyarakat Indonesia, akan tetapi pada kenyataannya masih banyak terdapat kesenjangan pendidikan antara perempuan dengan laki-laki. Pernyataan yang demikian sangatlah bertentangan dengan Pasal 131 ayat (1) Undang-Undang Dasar 1945 yang berbunyi, “ Bahwa setiap warga Negara Indonesia berhak mendapatkan pendidikan".

UNICEF mengungkapkan fakta bahwa data yang didapat dari Departemen Pendidikan masih nampak kesenjangan dalam pendidikan terhadap anak laki-laki dan anak perempuan. Menurut data ada 6 perempuan dari 10 anak ditingkat Sekolah Dasar yang tidak bisa melanjutkan sekolahnya. Adapun ditingkat Sekolah Menengah Pertama terdapat 7 anak perempuan dari 10 anak yang tidak bisa melanjutkan sekolah. Dari data tersebut jelas memperlihatkan bahwa terdapat ketidaksetaraan pendidikan yang didapatkan antara anak perempuan dan anak laki-laki. Hasil penelitian yang dilakukan oleh Valentina Sagala dalam Enny (2008) menyatakan bahwa pada tahun 2006 Angka Partisipasi Sekolah (APS) anak lakilaki lebih tinggi daripada anak perempuan, pada kelompok usia sekitar 7-12 tahun APS anak laki-laki sebesar 96,48\% dan pada anak perempuan sebesar 96,21\% sedangkan dalam kelompok usia 16-18 tahun APS laki-laki terdapat sebesar 52,48\% dan perempuannya 50,46\% (Ervani Faradillah, Nunung Nurwati, 2020).

Saat Nabi Muhammad Saw datang, segala sesuatu yang merendahkan martabat perempuan ataupun memarjinalkan kaum perempuan secara bertahap dihilangkan. Dalam Islam, yang dipandang mulia antar manusia tidak terletak pada jenis kelamin, fisik dan bukan pula pada hartanya. Namun terdapat pada ketakwaannya. Islam mengajarkan bahwa setiap anak merupakan rezeki dari Allah yang patut untuk disyukuri.

Dalam Islam, metode pendidikan secara luas adalah cara yang digunakan dalam upaya mendidik dengan nilai-nilai Islam (Tafsir, 2014). Adapun mendidik yang dimaksud menurut Arifin (Hasan, 1994) adalah membimbing dan mengarahkan pertumbuhan dan perkembangan dari tahap ke tahap kehidupan anak didik sampai mencapai titik kemampuan yang optimal.

Pada surat Ali Imran terdapat ayat yang menceritakan suatu kisah. Yaitu kisah tentang seorang ibu yang sangat mendambakan dan menunggu kehadiran seorang anak laki-laki, tetapi ketika diberi kesempatan untuk memiliki keturunan Allah Swt justru menganugerahinya seorang anak perempuan. Namun ibunya tetap tawakal pada ketentuan Allah Swt. Dia tidak bersedih ataupun kecewa dan memberikan pendidikan kepada anaknya hingga anak perempuannya menjadi perempuan yang sholehah.

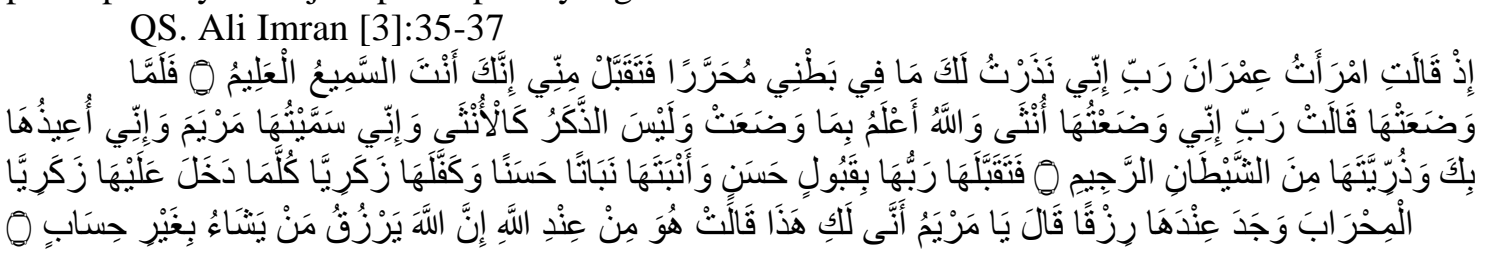

Dalam Al-Qur'an dikisahkan Maryam binti Imran selama masa hidupnya memperoleh pendidikan yang luar biasa, baik dari kedua orang tuanya terutama ibunya, dari Nabi Zakariya sebagai seorang pengasuh Maryam sekaligus seorang guru baginya, dan pendidikan dari malaikat Jibril yang menjelma menjadi manusia. Pendidikan yang diperoleh Maryam tersebut membuatnya tumbuh menjadi pribadi yang baik secara fisik maupun psikis.

Berdasarkan latar belakang yang telah diuraikan, maka perumusan masalah dalam penelitian ini sebagai berikut:

1. Bagaimana pendapat para mufasir mengenai Q.S Ali Imran ayat 35-37?

2. Apa esensi yang terdapat dalam Q.S Ali Imran ayat 35-37?

3. Bagaimana pendapat para ahli pendidikan mengenai pendidikan bagi anak perempuan?

4. Apa implikasi pendidikan yang dapat diambil dari Q.S Ali Imran ayat 35-37 mengenai pendidikan bagi anak perempuan?.

Selanjutnya, tujuan dalam penelitian ini dapat diuraikan sebagai berikut.

1. Untuk mengetahui pendapat para mufasir mengenai Q.S Ali-Imran ayat 35-37.

2. Untuk menjelaskan esensi yang terdapat dalam Q.S Ali Imran ayat 35-37.

3. Untuk mengembangkan pendapat para ahli pendidikan mengenai pendidikan bagi anak 
perempuan.

4. Untuk mendeskripsikan implikasi pendidikan yang dapat diambil dari Q.S Ali Imran ayat 35-37 mengenai pendidikan bagi anak perempuan.

\section{B. Metodologi}

Penelitian ini menggunakan metode deskriptif dengan pendekatan kualitatif. Dan teknik pengumpulan data studi kepustakaan. Untuk penelitian tafsir ini menggunakan metode tahli, yang mana membahas tentang makna, ayat yang dikandung dan surah-surah yang sesuai dengan urutan dalam mushaf.

Data yang digunakan dalam penelitian ini yaitu Q.S Ali Imran ayat 35-37. Data primer pada penelitian ini meliputi tafsir Q.S Ali Imran ayat 35-37 yang terdapat pada kitab-kitab tafsir, seperti: Tafsir Ibnu Katsir, Tafsir Al-Qurthubi, Tafsir Al-Maraghi, Tafsir Ath-Thabari, Tafsir Al-Muyassar, dan Tafsir Fi Zhilalil-Qur'an.

Adapun untuk data sekunder peneliti menggunakan sumber-sumber lain yang menunjang kebutuhan peneliti. Selain menggunakan tafsir yang relevan dengan objek kajian yang diteliti, penelitian ini pun ditambahkan dengan karya tulis lain, yakni buku-buku, internet serta sumber-sumber lain yang berkaitan dengan QS Ali Imran ayat 35-37 atau tentang pendidikan bagi anak perempuan.

\section{Pembahasan dan Diskusi}

\section{Orang Tua Harus Mendidik Anaknya Dalam Hal Kepatuhan Kepada Allah Swt}

Hannah mendidik Maryam dalam hal kepatuhan kepada Allah Swt adalah dengan memberinya pendidikan akidah, bahwa Hannah menginginkan anak yang sedang dikandungnya beribadah sepenuhnya kepada Allah dan menyerahkan anaknya untuk berkhidmat di tempat ibadah.

Memberikan pendidikan kepada anak dimulai dengan mendidiknya dalam agama yakni memberikan pendidikan akidah sejak anak masih dalam kandungan, ibunya Maryam memberikan contoh untuk mendidik anak supaya patuh kepada Allah Swt dengan cara mendoakan anaknya secara tulus kepada Allah, merdeka dan bebas dari semua ikatan kecuali menginginkan diterima oleh-Nya dan diridhai-Nya. Mendidik Anak Perempuan.

Dilihat dari sudut pandang etimologi, pendidikan berasal dari bahasa Yunani "Paedagogike". Yakni bentuk kata majemuk yang terdiri dari kata "Paes" yang memiliki arti "Anak" dan kata "Ago" yang mempunyai arti "Aku membimbing". Jadi "Paedagogike" artinya aku membimbing anak. Orang yang bekerja memberikan bimbingan kepada anak dengan tujuan membawa anak ke suatu tempat untuk belajar, sedangkan didalam bahasa Yunani yaitu "Paedagogos". Jika kata ini memiliki makna dari sisi konotasinya, maka perlakuan memberikan bimbingan ini seperti yang telah dijelaskan, adalah inti dari perbuatan memberi didikan yang mana pekerjaannya hanya untuk memberikan bimbingan saja, kemudian setelah selesai harus membebaskan anak itu kembali (ke dalam masyarakat) (Ahmadi dan Uhbiyanti, 2003:70).

Ahmad Tafsir memiliki pendapat bahwa pendidikan merupakan usaha peningkatan diri terhadap segala aspek, dengan kegiatan yang menyertakan pendidik ataupun tidak, entah itu aktifitas yang formal, non-formal ataupun informal yang mempunyai tujuan dalam memberikan pembinaan kepada peserta didik mengenai aspek karakter, jasmani, akal dan juga rohaninya (Ahmad Tafsir, 1994).

Anak perempuan merupakan para calon ibu di masa depan. Ibu merupakan sosok yang tentunya menjadi madrasah utama bagi setiap anak-anaknya. Untuk mencapai cita-cita memiliki anak yang baik, yang sholih/sholihah, cerdas namun juga kuat maka diperlukan pula sosok seorang ibu yang mempunyai kepribadian yang baik, sholehah, cerdas dan juga kuat (M. Fahmi Ilham, 2020).

Anak adalah anugerah serta nikmat yang harus disyukuri sebagai amanah dari Allah Swt, maka setiap anak harus dirawat, dijaga dan dididik agar ia tumbuh sesuai yang diinginkan orang tua. Sebab itu, anak merupakan tanggung jawab yang besar bagi setiap orang tuanya.

Menjaga diri sendiri dan keluarga salah satunya dengan menjadi pemimpin memberikan pendidikan yang baik bagi anggota keluarganya (anak dan istri). Orang tua memikul tanggung 
jawab atas anaknya, oleh sebab itu orang tua harus memperhatikan pendidikan anaknya.

1. Tujuan Pendidikan

Secara etimologis, tujuan memiliki arti sesuatu yang menjadi dambaan bagaikan seorang pemanah yang mendambakan anak panahnya dapat mencapai sasaran atau objek yang dipanah. Tujuan pendidikan juga dapat dimaknai sebuah objek atau sasaran yang hendak dicapai setelah proses pendidikan. Al-Quran memakai istilah al-qasd untuk menunjukkan arti tujuan seperti yang dijumpai dalam Qs. Al-Taubah/9:42. Tujuan pendidikan itu bersifat normative, karena mengandung unsur norma yang memiliki sifat memaksa namun tidak bertentangan dengan hakekat perkembangan manusia sebagai peserta didik. Tujuan pendidikan juga memiliki sifat abstrak, karena memuat nilai yang bersifat abstrak hingga tidak dapat dilihat oleh pancaindera, tetapi dapat dipahami dan dihayati oleh pemiliknya (Maman Karman, 2017).

Tujuan pendidikan pun tidak hanya ditanamkan pada saat manusia lahir, melainkan sejak masih berada dalam kandungan ibu hingga ia beranjak dewasa. Bahkan pada saat usia anak masih kecil pun pendidikan sudah diberikan dalam Undang-Undang No. 20 Tahun 2003 dalam pasal 3 yang berbunyi "pendidikan bertujuan untuk berkembangnya potensi peserta didik supaya menjadi manusia yang beriman dan bertakwa kepada Tuhan Yang Maha Esa, memiliki akhlak yang mulia, sehat, berilmu, cakap, kreatif, mandiri dan menjadi warga negara yang demokratis serta bertanggung jawab" (Yuli Sectio Rini, 2013).

Dalam masyarakat Makkah di masa Jahiliah, seorang ayah boleh membunuh bahkan mengubur hidup-hidup anaknya jika yang lahir adalah bayi perempuan. Pada zaman itu masih diyakini bahwa setiap anak perempuan yang lahir harus dibunuh, karena khawatir nantinya akan menikah dengan orang asing atau orang yang berkedudukan sosial rendah misalnya budak atau mawali (Nasaruddin Umar, 2010).

Begitu Islam datang, perempuan diangkat derajatnya diberikan hak-haknya secara penuh yakni dengan memberi warisan kepada perempuan, memberikan kepemilikian penuh terhadap hartanya, bahkan tidak boleh ada pihak lain ikut campur kecuali setelah diberi izin olehnya (Al-Rafi'i, 2002).

Tradisi di dalam agama Islam, bahwa perempuan mukallaf sudah memiliki hak untuk melakukan dan mengambil keputusan dalam berbagai perjanjian, sumpah maupun nazar, entah kepada sesama manusia ataupun kepada Tuhan (Nasaruddin Umar, 2010).

Islam sebagai sebuah ajaran yang memposisikan perempuan pada tempat yang mulia. Tidak ada diskriminasi peran antara laki-laki dan perempuan.

2. Hak-Hak Kaum Perempuan

a. Hak Beribadah

Perempuan pun perlu diberi kesempatan untuk mendapatkan pendidikan yang sempurna tanpa ada lagi perbedaan pendidikan berdasarkan jenis kelamin. Lebih dari itu, wanita seharusnya memiliki kompetensi-kompetensi tertentu dalam dirinya dalam melaksanakan perannya baik sebagai ibu, istri, profesi tertentu dan lain-lain (Nirman, 2015).

Setiap manusia entah laki-laki maupun perempuan pada dasarnya dilahirkan dengan memiliki hak yang sama (Betrand, 2010: 1581).

Hak perempuan untuk beribadah/beragama serta untuk masuk surga, bukan hanya dikuasai kaum laki-laki. Sebagaimana dalam QS An-Nișa' [4]: 124

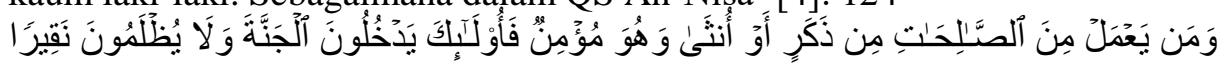

Ilmu pengetahuan sangat dijunjung tinggi dalam Islam dan orang-orang yang memiliki ilmu pengetahuan sangat dihargai. Bahkan dalam Hadis Nabi disebutkan yang artinya: "Menuntut ilmu itu sangat diwajibkan bagi setiap orang Islam, laki-laki dan perempuan" (M. Bahardin, 2012).

Perempuan dalam statusnya sebagai anak, memiliki hak untuk mendapatkan nafkah pendidikan dan pengasuhan hingga mereka menikah dan berumah tangga. Kewajiban ini tidak hanya diperintahkan untuk laki-laki saja namun juga kepada perempuan. Sebagaimana firman Allah Swt dalam QS Al-Mujadilah [58]:11. 


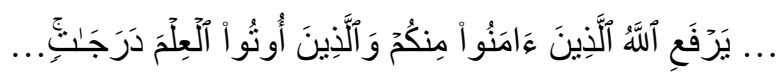

“...Allah akan Mengangkat (derajat) orang-orang yang beriman di antaramu dan orangorang yang diberi ilmu pengetahuan beberapa derajat..." (Depag RI, 2008:543).

b. Hak Menuntut Ilmu

Pendidikan adalah suatu upaya yang dilaksanakan oleh setiap individu baik laki-laki maupun perempuan untuk mentransmisikan nilai-nilai, kebiasaan, dan bentuk-bentuk ideal kehidupan dalam meneruskan aktivitas kehidupan secara efektif dan berhasil (Wahab, 2007).

Setiap manusia memiliki hak untuk menuntut ilmu. Tidak hanya bagi laki-laki, perempuan pun memiliki hak untuk menuntut ilmu. Apabila perempuan tidak atau belum bersuami, maka dia bisa mencari ilmu dan tidak boleh seorangpun melarangnya untuk belajar. Tetapi jika dia dalam keadaan telah menikah, apalagi ada anak maka ketika dia akan melanjutkan pendidikannya dia harus bermusyawarah serta

\section{Pendidikan Diberikan Bukan Berdasarkan Jenis Kelamin}

Membeda-bedakan anak dalam memberikan pendidikan merupakan hal yang buruk, sebab yang demikian itu sama saja membawa kembali pada sifat-sifat buruk dari masa jahiliyah. Sebagai seorang muslim, sudah sepatutnya menaati perintah Allah dan RasulNya, apalagi dalam memberikan kasih sayang dan cinta kepada anak tanpa melihat jenis kelaminnya. Seperti sabda Rasul Saw yang diriwayatkan oleh Ashabus Sunan dan Imam Ahmad, Ibnu Hibban dari hadits Nu'man bin Basyir semoga Allah meridhoinya:

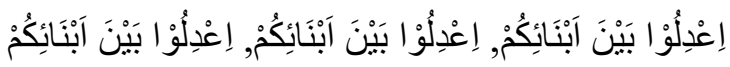

"Berlakulah secara adil kepada anak-anak kalian, berlakulah secara adil kepada anakanak kalian, berlakulah secara adil kepada anak-anak kalian" (Abdullah Nashih 'Ulwan: 2019).

Sebagai orang tua haruslah mengedepankan pendidikan yang unggul untuk anaknya. Para orang tua memiliki tanggung jawab pendidikan intelektual anaknya mengenai pembentukan dan pembinaan berfikir anak dengan segala sesuatu yang memiliki kebermanfaatan (Abdullah Nashih 'Ulwan, 1981).

Hannah sadar siapa dirinya dan keluarganya, mereka merupakan keturunan Bani Israil, sehingga Hannah sejak awal kehamilannya sangat ingin mengkhidmatkan anak yang dikandungnya itu beribadah dan bertakwa kepada Allah Swt. kemudian setelah lahir ia menyerahkan pengurusan anaknya kepada Nabi Zakariya yang juga dipilihkan oleh Allah untuk mengurus Maryam.

Meskipun orang tua tidak bisa mendidik anaknya secara langsung dikarenakan keterbatasan pengetahuan yang dimiliki oleh orang tuanya, bisa dengan memilihkan guru atau seorang pendidik bagi anaknya seperti yang dilakukan oleh Hannah ibu dari Maryam.

Menurut M. Fauzil Adhim terdapat 3 hal yang patut dipertimbangkan oleh para orang tua dalam memilihkan sekolah/pengajar untuk anaknya:

1. Keutuhan karakter para pendidiknya. Para pendidik yang memiliki karakter kuat dalam keutuhannya sebagai seorang pendidik akan mengutamakan nilai-nilai penting yang para pendidik itu pegang sekaligus akidah yang diyakini oleh mereka. Termasuk terhadap prinsip hidup yang mereka tegakkan.

2. Memiliki tekad yang kuat serta seberapa besar cintanya seorang pendidik terhadap pekerjaan dan perannya dan sebagai guru.

3. Berkompeten dalam aspek yang tentunya sesuai dengan keahliannya dalam disiplin ilmu yang akan disampaikan dan juga kecakapannya dalam menyampaikan ilmu kepada peserta didik (Adhim, 2012:73).

\section{Esensi Ayat}

Setelah mengkaji pendapat para mufasir maka dapat diambil esensi sebagai berikut:

1. Orang tua harus mendidik anaknya dalam hal kepatuhan kepada Allah Swt.

2. Pendidikan diberikan bukan berdasarkan jenis kelamin.

3. Orang tua harus memberikan pendidikan yang terbaik bagi anaknya.

4. Seorang Pendidik harus memberikan pendidikan dan pengasuhan yang baik. 


\section{Implikasi Pendidikan dari QS Ali Imran ayat 35-37 Tentang Cara Nabi Zakariya dalam Mendidik Anak Perempuan.}

1. Mendoakan Anak

Doa dari orang tua kepada anaknya mempunyai pengaruh besar dalam mendidik anak, karena itu Rasulullah Saw memberikan contoh saat seorang suami mendatangi istrinya untuk senantiasa berdoa kepada Allah Swt agar dikaruniai keturunan yang sholeh dan dijauhkan dari segala keburukan yang disebabkan oleh setan. Rasulullah Saw bersabda bahwa doa orang tua untuk anak akan dikabulkan.

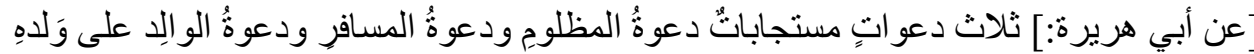

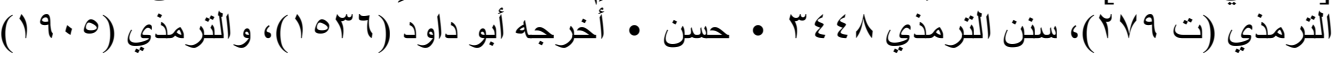
musafir, dan doa kedua orang tua terhadap anaknya" (HR. Abu Daud dan Tirmidzi).

Hannah bernazar ketika dia sedang mengandung, ini memberikan pesan bahwa pendidikan anak perempuan dalam hal ini bukan hanya ketika anak itu lahir melainkan jauh sebelum itu, sejak dalam kandungan. Hal ini juga memberikan pesan bahwa setiap istri atau calon ibu banyak mendoakan calon buah hati yang dikandungnya.

Kemudian setelah anaknya lahir, Hannah mendoakan agar anaknya beserta keturunannya kelak dijaga dari sentuhan setan. Memberi makna bahwa meminta perlindungan Allah untuk anak cucunya dari sentuhan syetan merupakan didikan lanjutan dari orang tua kepada anaknya setelah anaknya lahir. Juga meminta penjagaan kepada Allah memberikan makna bahwa bagaimanapun, sejak usia dini anak harus dikenalkan dengan Tuhannya, dengan cara mendoakan.

\section{Hak Pendidikan Bagi Anak}

Menurut Fuad Ihsan, tanggung jawab pendidikan oleh kedua orang tua meliputi:

1. Memelihara serta membesarkannya. Tanggung jawab ini adalah hal yang harus terpenuhi sebab merupakan kebutuhan yang alami untuk dilaksanakan, karena anak memerlukan asupan makanan, minuman dan juga perawatan, agar ia bisa hidup secara berkelanjutan.

2. Melindungi serta menjamin kesehatannya, bukan hanya secara jasmani tetapi kesehatan rohani pun harus diperhatikan, juga dari gangguan berbagai penyakit atau bahayanya lingkungan yang bisa membahayakan dirinya.

3. Memberikan pendidikan dengan berbagai macam ilmu pengetahuan dan berbagai keterampilan yang berguna bagi kehidupannya, sehingga apabila dewasa ia mampu berdiri sendiri dan membantu orang lain serta melaksanakan fungsi kekhalifahannya.

4. Memberikan kebahagiaan untuk anak di dunia dan akhirat dengan memberikan pendidikan agama sesuai dengan perintah Allah dan RasulNya sebagai tujuan akhir hidup bagi seorang muslim. Tanggung jawab ini disebut juga sebagai tanggung jawab kepada Allah (Fuad Ihsan, 1997).

Dalam kisah ini, Allah Swt memilih Zakariya untuk mengasuh Maryam selain karena beliau merupakan hamba shaleh dan berilmu, juga karena Zakariya masih mempunyai nasab dengan ibunya Maryam yaitu dari istrinya sebagai saudara perempuan dari ibu Maryam (bibi). Sehingga, saudara perempuan ibu itu punya kedudukan untuk memelihara anaknya jika salah satu atau dari keduanya meninggal.

$$
\text { الخالَةُ بمنزِلة الأُم }
$$

"Saudara perempuan dari ibu memiliki kedudukan seperti ibu" (Al-Tharifi. Abdul Aziz bin Marzuki, 2017).

Masih banyak orang tua yang tidak mengetahui bahwa anak perempuan mereka pun berhak untuk diberikan pendidikan dari orang tuanya. Sebab mereka menganggap bahwa anak perempuan tidak terlalu membutuhkan pendidikan. Karena orientasi dan pemikiran orang tua yang sempit bahwasannya pendidikan sebagai jalur untuk mencari uang atau mendapatkan pekerjaan.

\section{Kesimpulan}

Berdasarkan pembahasan dalam penelitian ini, peneliti dapat menarik kesimpulan dari beberapa hasil penelitian sebagai berikut: 
1. Pendapat Para Mufassir Tentang Qs Ali Imran ayat 35-37

Ayat-ayat ini menceritakan tentang nazar Hannah yaitu ibu dari Maryam yang ingin mengkhidmatkan anaknya untuk beribadah kepada Allah. Meskipun terdapat kekecewaan karena anak yang dikandungnya itu ketika dilahirkan ternyata bayi perempuan, namun Hannah tetap ikhlas dan menerima ketetapan Allah Swt, dengan tetap memberikan pendidikan yang terbaik lewat Nabi Zakariya.

Terpilihnya Nabi Zakariya sebagai orang yang mendidik Maryam selain karena beliau adalah pamannya, juga karena Nabi Zakariya merupakan manusia pilihan Allah yang paling banyak amal baiknya dan juga tinggi ilmunya.

2. Esensi Qs Ali Imran ayat 35-37

Esensi dari QS. Ali Imran ayat 35-37 adalah sebagai berikut:

○ Orang tua harus mendidik anaknya dalam hal kepatuhan kepada Allah Swt.

- Pendidikan diberikan bukan berdasarkan jenis kelamin.

- Orang tua harus memberikan pendidikan yang terbaik bagi anaknya.

- Seorang Pendidik harus memberikan pendidikan dan pengasuhan yang baik.

3. Pendapat Para Ahli Tentang Cara Nabi Zakariya dalam Mendidik Anak Perempuan

Pendidikan bagi anak perempuan meliputi: (1) Pendidikan terhadap jasmaninya, (2)

Pendidikan akan rohaninya, (3) Pendidikan tentang mentalnya, (4) Dan pendidikan mengenai sosialnya. Masih banyak orang tua yang tidak mengetahui bahwa memberikan pendidikan kepada anak perempuan merupakan kewajiban yang harus terpenuhi, sudah merupakan hak seorang anak perempuan pula untuk mendapatkan pendidikan dari orang tuanya meliputi: (1) Mempunyai visi besar, (2) Mempunyai bekal, (3) Memotivasi, (4) Mendoakan anak, (5) Memiliki perangai baik pada anak, (6) Memberikan sekolah/pengajar yang baik.

4. Implikasi Pendidikan dari Qs Ali Imran ayat 35-37

Implikasi pendidikan dari QS. Ali Imran ayat 35-37 meliputi: (1) Mendoakan anak, (2) Memerintahkan anak untuk beribadah kepada Allah Swt, (3) Menjadi figur dalam ketaatan kepada Allah Swt, (4) Memberikan hak pendidikan bagi anak, (5) Memberikan kesempatan dalam pendidikan kepada anak perempuan. Cara mendidik anak perempuan yang dilakukan oleh Nabi Zakariya yaitu: (1) Menempatkan pada lingkungan yang baik, (2) Mendidik dengan pengawasan dan perhatian, (3) Mendidik dengan keteladanan dalam beribadah juga dalam bersikap.

\section{Daftar Pustaka}

[1] Ahdiah, Indah. "Peran-Peran Perempuan Dalam Masyarakat. Jurnal Academia Vol 05 No 02, 2013, 1085-1092.

[2] Al-Harāri, Muhammad al-Amin bin 'Abdullah. Tafsīr Hadāiq al-Raih wa al-Raihān fì Rawābiy 'Ulūm al-Quran. Beirut: Dar Thauq al-Najāh (IV: 274). 2001.

[3] Al-Quran Al-Karīm. Terjemah Departemen Agama Republik Indonesia.

[4] Karman, Maman. Ulum Al-Qur'an dan Tafsir Tarbawi. Cet. 1. Hiliana Press. Jakarta. 2017.

[5] Ulwan, Abdullah Nashih. Pendidikan Anak Dalam Islam. Cet. 11. Insan Kamil. Sukoharjo, Jawa Tengah. 2019. 